URL: https://zakon.rada.gov.ua/laws/show/995_042\#Text (дата звернення: 19.04.2021).

13. Органы ООН по правам человека. URL: http://www.ohchr.org/RU/ HRBodies/Pages/HumanRightsBodies.aspx (дата звернення: 19.04.2021).

14. Погребной И. М. Теория права : учебное пособие. 3-е изд., испр. и доп. Х.: Государственное специализированное издательство «Основа», 2003. $122 \mathrm{c.}$

15. Романов В. В. Юридическая психология: учебник. М.: Юристь, 1998. 488 с.

16. Рада ООН 3 прав людини. URL: https://www.ohchr.org/ EN/HRbodies/HRC/Pages/Home.aspx (дата звернення: 19.04.2021).

17. Факультативний протокол до Конвенції про права осіб 3 інвалідністю: протокол ООН від 13.12.2006, в ред. від 06.07.2016. URL: https://zakon.rada.gov.ua/laws/show/995_g72\#Text (дата звернення: 19.04.2021).

18. Факультативний протокол до Міжнародного пакту про економічні, соціальні і культурні права: протокол ООН від 10.12.2008. URL: https://zakon.rada.gov.ua/laws/show/995_i50\#Text (дата звернення: 19.04.2021).

19. Хартія основних прав Свропейського Союзу: хартія $\mathrm{CC} \mathrm{від}$ 07.12.2000. URL: https://zakon.rada.gov.ua/laws/show/994_524\#Text (дата звернення: 19.04.2021).

20. Черданцев А. Ф. Теория государства и права: учебник для ВУЗов. М.: Юрайт, 2002. 432 с.

DOI https://doi.org/10.30525/978-9934-26-074-2-3

\title{
РОЗГЛЯД СУДАМИ СПРАВ ПРО РОЗІРВАННЯ ШЛЮБУ У ЗАХІДНИХ ОБЛАСТЯХ УРСР В 1944-1953 РР.
}

\author{
Думанівська А. Я. \\ судовий розпорядник \\ Львівського окружного адміністративного суду \\ м. Львів, Україна
}

Відповідно до глави 26-а ЦПК 1929 р., до цивільних справ окремого провадження були віднесені справи про розірвання шлюбу. Окреме провадження передбачалось як безспірне провадження. Незважаючи на виділення в цивільному процесі окремого провадження як відносно самостійного, загальні для всіх справ окремого провадження норми, які регулювали б порядок їх розгляду, не були сформульовані [4, с. 34, 42]. 
Розгляд справ даної категорії мав ряд процесуальних особливостей, які відображені в Указі Президії Верховної Ради СРСР від 8 липня 1944 р. і в Інструкці НКЮ СРСР № 58 «Порядок розлляду судами справ про розірвання шлюбу», затвердженою постановою РНК СРСР № 1622 від 27 листопада 1944 р. [3, арк. 53].

Основна особливість судочинства по розірванню шлюбу полягала в тому, що діяли дві стадії судового розгляду: стадія примирення в (народному) суді і стадія вирішення справи про розірвання шлюбу по суті у вищій судовій інстанції (обласному суді). Вимагалося обов'язкове зазначення мотивів розлучення, передбачалися публічність провадження та підвищення судового збору з цих справ.

Однак, із загального правила були й винятки. Так, розірвання шлюбу ставало можливим у разі визнання одного з членів подружжя безвісті відсутнім протягом не менше трьох років, його засудженння чи визнання душевно хворим.

Головним завданням, покладеним на суд, ставало «з'ясувати причини розлучення i примирити подружжя, довівши їм необгрунтованість i несерйозність їхніх мотивів розлучення». Ці справи розглядались за участю народних засідателів [5, с. 3-4], то ж винесення на люди брудної білизни ставало неминучим.

Відповідно до інструкції, народний суд як перша інстанція мав розглядати справи про розірвання шлюбу за спільною заявою подружжя або за заявою одного з них. При подачі заяви про розірвання шлюбу стягували 100 крб. судового збору, а також суму, необхідну для оплати друку оголошення в газеті (п.п. «а» $\mathrm{i}$ «в» ст. 24 Указу ПВР СРСР від 8 липня 1944 р.) [4, с. 113].

Суддя, що прийняв заяву у справі про розірвання шлюбу, встановлював свідків і опитував їх, подавав оголошення в місцевій газеті про порушення заявником справи про розірвання шлюбу (п. 7 Інструкції НКЮ СРСР № 58 від 27 листопада 1944 р.). Після цього суддя повинен був надіслати заяву та інші матеріали в справі, додавши опубліковане в газеті оголошення, до суду за місцем проживання сторін (однієї сторони), наприклад, дружини-відповідача (п. «б» ст. 24 Указу ПВР СРСР від 8 липня 1944 р.).

Закінчивши досудову підготовку справи, суддя мав подати відповідні оголошення у місцеву газету і призначити слухання справи. Такі справи розглядались у відкритому судовому засіданні (п. 12 Інструкції) [4, c. 114].

У ст. 25 Указу ПВР СРСР від 8 липня 1944 р. ваказувалося, що у справах про розірвання шлюбу до суду «обов'язково повинні бути викликані обидва подружжя, що розривають шлюб». Однак, деякі судді розглядали такі справи без участі однієї із сторін, крім того, учасників процесу деколи взагалі не повідомляли про розгляд справи. Наприклад, 
суд Лаповецького району Тернопільської області прийняв ухвалу про розірвання шлюбу між подружжям Довгалюком і Янишевич у зв'язку із непримиренням сторін за відсутності відповідача, котрого до суду навіть не викликали.

Народний суд Коропецького району Тернопільської області наприкінці 1947 p. розглянув справу за позовом гр. Звєрева до гр. Звєревої про розірвання шлюбу за відсутності сторін [6, с. 35].

3 цього приводу в Постанові Пленуму Верховного Суду СРСР вid 7 травня 1948 p. здійснено роз'яснення, що у справах про розірвання шлюбу явка позивача $\mathrm{i}$ відповідача в судове засідання є обов'язковою [8, с. 16].

3'ясувавши усі обставини справи, народні судді могли виносити лише ухвалу про примирення чи непримирення сторін. Саме рішення про розірвання шлюбу могло бути прийняте виключно обласним судом. Відповідно до ст.ст. 26 і 27 Указу ПВР СРСР від 8 липня 1944 р., обласний суд, якщо він визнавав за можливе розірвати шлюб між подружжям, мав визначити, при кому із подружжя залишаться діти; хто iз подружжя і в якій мірі несе витрати на утримання дітей; вирішити питання про поділ спільно нажитого майна; а також накласти стягнення на одного із членів подружжя (від 500 до 2000 крб.) за отримання свідоцтва про розлучення [6, с. 36].

Деякі народні судді намагалися у повному дотримуватися інструкцій [1, арк. 101 зв.]. Зокрема, щоб виконати настанови «будь-якою ціною примирити подружжя», судді ігнорували навіть очевидні мотиви розлучення.

Прикладом може сдужити справа, розглянута в суді 3-ї дільниці м. Рівне і Верховним судом Української РСР.

Отже, по суті: 8 квітня 1952 р. громадянка С. зареєструвала свій шлюб з гр. С. який раніше перебував у шлюбі, але завірив іiі, що перший свій шлюб він формально розірвав 6 вересня 1944 р., тобто після видання Указу ПВР СРСР від 8 липня 1944 р. У подружжя С. народився син, котрого зареєстрували під прізвищем С. Знайшовши у чоловіка переписку з першою дружиною, та дізнавшись про те, що попередній шлюб все ще не розірваний, С. звернулась в суд 3-ї дільниці м. Рівне із заявою, в якій просила розірвати шлюб з С. як незаконний і позбавити його прав батьківства щодо сина, та повернути ӥй їі дошлюбне прізвише, під яким записати й сина.

Народний суд (нижча інстанція) у зв'язку 3 неможливістю примирення сторін прийняв ухвалу про закінчення попереднього розгляду справи. Далі за заявою позивачки справа надійшла на розгляд в Рівненський обласний суд. Обласний суд, керуючись ст. 26 Указу ПВР СРСР від 8 липня 1944 р., розглянув цю справу у порядку ст.ст. 111 і 114 Кодексу законів про сім'ю і шлюб та вирішив визнати шлюб між 20 
подружжям С. недійсним, позбавити відповідача батьківських прав щодо сина, повернути позивачці іiі дошлюбне прізвище і надати їй право зареєструвати сина за іiі дошлюбним прізвищем, а по-батькові - за іiі бажанням як одинокій матері. Крім того, поділити майно між сторонами, виділити відповідачеві перераховане в рішенні майно в натурі чи його вартість в сумі 1120 крб. [7, с. 27].

Верховний суд Української РСР залишив це рішення обласного суду у силі.

Встановлений радянськими законами порядок розлучення поширювався i на подружжя, один 3 членів якого мав іноземне громадянство. Про це свідчить архівний документ - Лист Міністерства юстиції УРСР № 5А-24159 від 26 травня 1953 р. до начальника Управління юстиції у Дрогобицькій області Гаврилюка Л.З., в якому вказується, що «розгляд справ про розірвання шлюбу між подружжям, один $з$ членів якого має громадянство іншої держави і проживає за кордоном, а інший в СРСР, проводиться в загальному порядку, встановленому Інструкцією НКЮ СРСР від 27 листопада 1944 р.». Зокрема, відповідно до постанови Пленуму Верховного суду СРСР від 3 березня 1950 р. «Про порядок виконання судових доручень 3 цивільних справ судів іноземних держав», повідомлення про день слухання справи мають спрямовуватися через Верховний суд УРСР до Міністерства закордонних справ СРСР [2, арк. 20-21].

\section{Література:}

1. Акт ревизии народного суда Выжницкого района Черновицкой области // Акты ревизии и обследования работы народных судов [Черновицкой] области: 13 января - 20 сентября 1947 г. ДАЧО. (Державний архів Чернівецької області). Ф. Р-38. Оп. 3. Спр. 45. Арк. 97-105.

2. Лист МЮ СРСР № 5А-24159 від 26 травня 1953 р. // Распоряжения Министерства юстиции УССР: 2 января - 16 декабря 1953 г. ДАЛО. (Державний архів Львівської області). Ф. Р-1371. Оп. 1. Спр. 78. Арк. 20-21.

3. Лист МЮ СРСР № 3-0170-46 від 27 лютого 1953 р. // Распоряжения Министерства юстиции УССР: 2 января - 16 декабря 1953 г. ДАЛО. (Державний архів Львівської області). Ф. Р-1371. Оп. 1. Спр. 78. Арк. 53-60.

4. Цивільний процесуальний кодекс УРСР. (Затв. ЦВК і РНК Української РСР 5 листопада 1929 р). Офіц. текст із змін і доп. на 1 липня 1949 р., $з$ постатейними матеріалами і додатками. Київ: Держ. вид-політ. літер. УРСР, 1949. С. 34-43.

5. Аксененок Г.А. Роль суда в укреплении семьи в советском государстве. Социалистическая законность. 1949. Март. № 3. С. 3-11. 
6. Дела о расторжении брака в Украинской ССР. Социалистическая законность. 1948. Сентябрь. № 9. С. 35-36.

7. Сусло Д.С. Недостатки практики судов Украинской ССР по делам о расторжении брака. Социалистическая законность. 1947. Апрель. № 4. С. 26-27.

8. Хохлов Н. Недостатки в работе некоторых судов по делам о расторжении брака. Социалистическая законность. 1949. Ноябрь. № 11. C. 15-19.

DOI https://doi.org/10.30525/978-9934-26-074-2-4

\title{
ІМПЕРСЬКА БІЛЬШОВИЦЬКА ПОЛТТИКА ГЕНОЦИДУ УКРАЇНСЬКОГО НАРОДУ ЧЕРЕЗ ОРГАНІЗАЦІЮ ШТУЧНИХ ГОЛОДОМОРІВ
}

\author{
Дурнов С. С. \\ доктор юридичних наук, професор, \\ начальник відділу \\ Департаменту персоналу Міністерства внутрішніх справ Украӥни \\ м. Київ, Україна \\ Сокур Ю. В. \\ кандидат юридичних наук, доцент, \\ дочент кафедри історії держави та права \\ Національної академії внутрішніх справ \\ м. Київ, Украӥна \\ Щербатюк В. М. \\ доктор історичних наук, професор, \\ професор кафедри історії держави та права \\ Національної академії внутрішніх справ \\ м. Київ, Украӥна
}

Слід зазначити, що для радянських дослідників і вчених тема Голодомору була закритою. Офіційна ідеологія і пропагандистська машина комуністичної партії стверджувала, що такого явища взагалі не існувало. Понад півстоліття трагедія Голодомору в Україні 1932 - 1933 pp. перебувала поза увагою світової громадськості. Лише у листопаді 1998 р. у 65-річчя найстрашнішого геноциду українського народу вперше 